7-31-2018

\title{
Training program to support preparedness of elderly health care services
}

Vita Priantina Dewi

Centre for Ageing Studies Universitas Indonesia, vitapriantinadewi@yahoo.com

Raden Irawati Ismail

Centre for Ageing Studies Universitas Indonesia

See next page for additional authors

Follow this and additional works at: https://scholarhub.ui.ac.id/ajce

Part of the Social and Behavioral Sciences Commons

\section{Recommended Citation}

Dewi, Vita Priantina; Ismail, Raden Irawati; and Kusdhany, MF Lindhawati (2018). Training program to support preparedness of elderly health care services. ASEAN Journal of Community Engagement, 2(1). Available at: https://doi.org/10.7454/ajce.v2i1.87

Creative Commons License

(c) (i) ()

This work is licensed under a Creative Commons Attribution-Share Alike 4.0 License.

This Research Article is brought to you for free and open access by the Universitas Indonesia at ASEAN Journal of Community Engagement. It has been accepted for inclusion in ASEAN Journal of Community Engagement. 


\title{
Training Program to Support Preparedness of Elderly Health Care Services

\author{
Vita Priantina Dewi ${ }^{{ }^{*}}$, Raden Irawati Ismaila ${ }^{a}$ MF Lindawati Kusdhany ${ }^{a}$
}

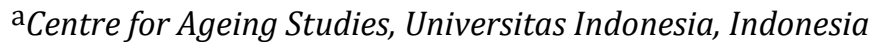

Received: October 23 $3^{\text {rd }}, 2017$ || Revised: November 20 $0^{\text {th }}$, December $1^{\text {st }} 2017$, July $18^{\text {th }}$ and $30^{\text {th }}, 2018$ || Accepted: July $30^{\text {th }}, 2018$

\begin{abstract}
The number of elderly people in Indonesia is estimated to reach 29 million in 2020 . The ageing process is usually followed by poor health which has been associated with risk of severe cognitive impairment. However, there is a limited training on older people's health and cognitive impairment. Thus, programmes emphasising on trainings for health cadres, health workers and physicians are encouraged to improve older persons' health. Additionally, health conditions of older persons have a relationship with cognitive impairment. There was 39\% (thirty nine percent) of the elderly who experienced cognitive impairment in several cities and villages in Indonesia. Therefore, this study aimed to provide training to develop and improve the ability of doctors, health workers and health cadres in conducting counselling for other cadres and health workers on HVLT (Hopkins Verbal Learning Test) and MMSE (Mini Mental State Examination) instruments to measure the cognitive status of elderly people. The method was PRA in relation with the definition of community development as the employment of community to address the needs and empower groups of people. PRA was also employed together with HVLT, MMSE and a training module. Participants were health cadres, public health workers and physicians. The results of the training program showed that in three months, $61 \%$ of 108 cadres showed cognitive improvement and $39 \%$ of them needed remedial. Training feedback assessment showed that $81 \%$ up to $90 \%$ cadres performance was good to excellent. $94 \%$ of 36 health workers showed cognitive improvement. Behavioural assessment showed $100 \%$ of respondents was cooperated and could share their opinions. The study concluded that a training program might be potential for cognitive improvement and the readiness of elderly people, cadres, health workers, and physicians to support elderly health care system in Depok City.
\end{abstract}

Keywords: ageing, behavioural assessment, cognitive function, health service, Depok City, Indonesia

\section{Introduction}

Population is ageing in Indonesia. The rising in life expectancies has caused the increasing of elderly people proportion aged 60 and above in this country. The number of elderly people in Indonesia is estimated to reach 29 million in 2020 (Ine, 2012; Govinda, 2008). One of Indonesia cities that has increasing number of older persons is Depok. The proportion of elderly people in Depok has exceeded the proportion of elderly nationally which is $9 \%$ (national rate 7\%), while its life expectancy is 73 years old (Fatmah, Dewi, Yudarini and Diponegoro, 2014; Ismail, Kusdhany, Iratanti and Dewi, 2014). As an increasing of age, there are several consequences on health of older persons such as physical limitation and multiple diseases. The National Socio-Economic Survey found that 29.2 percent of older persons reported having one health problem, 23.5 percent of them reported having at least two health problems and 47.3 percent of older persons reported not having health problem (Komisi Nasional Lanjut Usia, 2011). The percentage of having no health problem is the highest among those aged 60-64 years old with 53.5 percent, and the lowest (34.5 percent) among those aged 85-97.

In Depok, it is predicted that there will be an increase in the number of older people who are in risk of deteriorating health and cognitive status decline (Ismail, Kusdhany, Iratanti and Dewi, 2014). In other words, the ageing process is usually followed by poor health which also has been associated with risk of severe cognitive impairment. This

*Correspondence Author: vitapriantinadewi@yahoo.com 
Vita Priantina Dewi, Raden Irawati Ismail, MF Lindawati Kusdhany | ASEAN Journal of Community Engagement | Volume 2, Number 1, 2018

decrease in health varies between age and optimal physical and mental health conditions ranging from the average of cognitive status, severity and depression to severe cognitive status such as dementia (Ismail, Kusdhany, Iratanti and Dewi, 2014). Decreased cognitive status in old age includes aspects of ability to think, memory and decision-making that can affect the ability of work and social role every day (Hogervorst, Combrinck, Lapuerta, Rue, Swales, and Budge, 2002). The results of a study by Widyastuti found that the number of people with cognitive impairment continues to increase along with the increasing number of elderly people in Depok (Widyastuti, 2009).

Several diseases that are often suffered by the elderly are rheumatic, hypertension, heart disease, lung disease (bronchitis / dyspnoea), diabetes mellitus, falls, paralysis, pulmonary tuberculosis, fractures, cancer and dementia. Another study by Hogervorst and colleagues explains that in Indonesia, the risk of mental health disorder in the elderly in the form of dementia in rural areas is 2 to 3 times higher when compared with urban areas (Hogervorst and Rahardjo, 2007). This study also found a link between behaviour and lifestyle that can protect the elderly against the occurrence of poor health and decreased cognitive status. These behaviours and lifestyles are related to nutrition, engaging in physical and mental activity, as well as smoking habits. These behaviours are all known to have a significant association with cognitive status in a cross-sectional study of Indonesian society, whether by age; gender; level of education; and location of residence (Hogervorst, Combrinck, Lapuerta, Rue, Swales, and Budge, 2002).

To answer on the existing of older people's health problems, local government in Depok has carried out elderly health care program at 32 primary health care services (puskesmas) in 11 sub-districts. There are also 5 age-friendly community health services (puskesmas santun usia lanjut) and 576 specific community services for elderly people or posbindu lansia (Fatmah, Dewi, Yudarini and Diponegoro, 2014) to provide solutions of elderly people's health problems including cognitive impairment of the elderly. According to local health office, almost half of Depok elderly people has joined posbindu lansia. In other words, local government currently has paid attention in providing health care services for older persons in Depok. However, there is a limited training on older people's health and cognitive impairment that are conducted for medical doctors and cadres in primary health care services such as the HVLT (Hopkins Verbal Learning Test) and MMSE (Mini Mental State Examination) trainings. HVLT and MMSE trainings for medical doctor and health cadres can help in measuring cognitive status as part of community service programs. The benefits of these trainings for early detection of cognitive impairment of the elderly is for measuring cognitive status, for public educating on prevention of decreasing in cognitive function and for socialising to the wider community, medical doctors and health cadres so that they can conduct examination in order to find cases of elderly people cognitive impairment.

Ageing is characterised by changing in mental and physical functions. These changes vary in physical and mental health conditions, as well as in cognitive status (Hogervorst and Rahardjo, 2007). It can be said that health conditions of older persons have a relationship with cognitive impairment. A study conducted by Hogervorst and Rahardjo in 2007 showed that there were $39 \%$ (thirty nine percent) of the elderly who experienced cognitive impairment in several cities and villages in Indonesia (Hogervorst and Rahardjo, 2007). Decrease in cognitive status in general is often regarded as a normal process of ageing. Increased life expectancy will cause the number 
Vita Priantina Dewi, Raden Irawati Ismail, MF Lindawati Kusdhany | ASEAN Journal of Community Engagement | Volume 2, Number 1, 2018

of elderly people to grow, so the impact of cognitive decline began to be perceived as a burden economically and socially.

Along with the aging process, there is a shift in the pattern of disease, from infectious diseases to non-communicable diseases with all the consequences. In this case, individual behaviour, family and community health services (including primary health care services or puskesmas) play an important role in health promotion including in disease prevention. One of the community health services is the age-friendly community health services (puskesmas santun usia lanjut) which focuses on improving older people's quality of life (Komisi Nasional Lanjut Usia, 2011). In this regard, trainings of HVLT and MMSE for medical doctor and health cadres are part of this community service programs.

Decrease in cognitive status is often found in elderly at primary health care, with a prevalence of $15-35 \%^{2}$. The primary health care study by Valcour and colleagues concluded that $78.6 \%$ of patients with mild dementia, $71.4 \%$ with moderate dementia, and $20 \%$ with severe dementia had no record of cognitive status deterioration in their medical records (Hogervorst and Rahardjo, 2007; Ismail, Kusdhany, Iratanti and Dewi, 2014). In reality the deterioration of cognitive status in elderly people is undetectable in the community as well as at the primary health care. Many patients (50-66\%) with undiagnosed dementia are from primary health care (Hogervorst and Rahardjo, 2007; Ismail, Kusdhany, Iratanti and Dewi, 2014). Doctors often focus on the physical symptoms that the elderly complain about and ignore the mental status experienced. If the doctor can perform early detection and management of mental disorders that exist in the elderly people then this will be very useful to improve the physical condition and cognitive status as well as quality of life. However, there is a limited training on older people's health and cognitive impairment. Thus, programmes emphasising on trainings for health cadres, health workers and physicians are encouraged to improve older persons' health. The aim of this study is to provide training to develop and improve the ability of doctors, health workers and health cadres in conducting counselling for other cadres and health workers on HVLT and MMSE instruments to measure the cognitive status of elderly people in puskesmas and posbindu in 6 sub-districts in Depok in order to support the preparedness of elderly health services starting from the general public to basic health services in Depok.

\section{Methods}

The method of this study was Participatory Rural Appraisal (PRA) which is suitable for small or large number of groups of people. Narayanasamy (2009) stated that PRA was an incorporation of knowledge and opinions of people in planning and developing a program. It can be said that PRA is a method that can enable people to share, improve, and analyse their knowledge. It also included a mutual learning and involvement of all group members. In this study, PRA was employed in line with Mendes' (2009) definition of community development as the employment of community to address the needs and empower groups of people. It was also employed in line with JH Schiele's definition of community development as cited by Tan (2009) that the work community development as collective problem solving, self-help, and empowerment.

Therefore, a direct engagement in community development was crucial in creating a sustainable environment where the spirit of cooperation, mutual sharing and selfdetermination can often make a difference.

Participants in this study were 294 health cadres and health workers. Participants of health workers consisted of public health workers and physicians. All participants were 
Vita Priantina Dewi, Raden Irawati Ismail, MF Lindawati Kusdhany | ASEAN Journal of Community Engagement | Volume 2, Number 1, 2018

gathered at a designated place at the training location which was at Universitas Indonesia. Universitas Indonesia was selected as the training location because of participants' familiarity and close proximity to the site. Cognitive status indexes were trained for doctors, health workers and health cadres by using the Mini Mental State Examination (MMSE) and Hopkins Verbal Learning Test (HVLT). The Mini Mental Status Examination consists of a series of questions designed to measure change in cognitive status and to differentiate between normal age-related cognitive decline and the pathological cognitive decline that occurs in dementia (Hogervorst, Combrinck, Lapuerta, Rue, Swales and Budge, 2002; Darmojo and Martono, 2000).

The MMSE was used in conjunction with another test, the HVLT. Hopkins Verbal Learning Test (HVLT) is a brief verbal learning and memory test which only takes about 5 min to administer and is well tolerated by patients. This is a word learning test measuring episodic memory, which consists of 12 words from 3 low frequency categories (for version A: 'human shelter'; 'animals' and 'precious stones'). These words are all repeated 3 times to obtain a total immediate recall measure ('learning ability'). After $20 \mathrm{~min}$, a delayed recall without cues or prompting is done (Hogervorst, Combrinck, Lapuerta, Rue, Swales and Budge, 2002; Darmojo and Martono, 2007).

The training also employed a module and an index made by Prof. Dr. dr. Raden Irawati Ismail, Sp.KJ(K), M.Epid. The index was socialised to health workers and trained health cadres. Then the cadres and health workers will forward it to other cadres and health workers on an ongoing basis. The training started with a pre-test and ended with a post-test in order to find out whether there was an increase in knowledge and this was confirmed. In addition, as mentioned earlier, community health services (including primary health care services or puskesmas) play an important role in health promotion. One of the community health services is the age-friendly community health services (puskesmas santun usia lanjut) which focuses on improving older people's quality of life (Komisi Nasional Lanjut Usia, 2011). In this regard, trainings of HVLT and MMSE for medical doctor and health cadres are part of this community service programs.

\section{Results and Discussion}

Phase 1. The training for health cadres and health workers was conducted in 4 groups as seen in the table below:

Table 1. Training for health cadres and health workers phase 1

\section{Group Number of Note participants}

\begin{tabular}{ccl}
\hline 1 & 47 & Health cadres \\
\hline 2 & 50 & Health cadres \\
\hline 3 & 61 & Health cadres \\
\hline 4 & 43 & Health workers \\
\hline & & $\begin{array}{l}\text { (including doctors and } \\
\text { nurses) }\end{array}$
\end{tabular}


Vita Priantina Dewi, Raden Irawati Ismail, MF Lindawati Kusdhany | ASEAN Journal of Community Engagement | Volume 2, Number 1, 2018

Phase 2. A training for health cadres and health workers was conducted in 3 groups. The aim was to refresh the materials that have been given in previous training (see table below).

Table 2. Training for health cadres and health workers phase 2

\section{Group Number of Note participants}

\begin{tabular}{ccl}
\hline 1 & 26 & $\begin{array}{l}\text { Health cadres and health } \\
\text { workers }\end{array}$ \\
\hline 3 & 26 & Health cadres and health \\
\hline 4 & 116 & $\begin{array}{l}\text { TOT provided by health cadres } \\
\text { TOT provided by health } \\
\text { cadres }\end{array}$ \\
\hline 5 & 11 & Health cadres \\
\hline & 96 & TOT provided by health cadres \\
\hline & 9 & Health cadres and health workers \\
\hline & & TOT provided by health cadres \\
\hline
\end{tabular}

Activities undertaken in these trainings were:

1. Health cadres/trained health workers provided trainings on the use of MMSE and HVLT instruments to measure cognitive status of the elderly

2. Health cadres/trained health workers provided trainings on the prevention of elderly cognitive function reduction for other health cadres

3. Evaluation was conducted by resource persons with assessment criteria based on the activity and ability of participants.

In general, the training proved that there was an increase in participants' knowledge and skills. The results of the training program showed that in three months, $61 \%$ of 108 health cadres showed cognitive improvement and 39\% of them needed remedial. Training feedback assessment showed that $81 \%$ up to $90 \%$ health cadres performance was good to excellent. $94 \%$ of 36 health workers showed cognitive improvement. Behavioural assessment showed $100 \%$ of respondents cooperated and could share their opinions.

\subsection{Training of Health Cadres}

At the second phase, second group of health cadres was trained by first group of health cadres who had received initial training and refreshing training. This training was carried out three times. The number of health cadres who voluntarily attended trainings was more than expected. The initial plan of health cadres to participate in the training was 150 people, but then health cadres who attended the trainings reached 186 people. Prior to and after trainings, a pre-test and a post-test were held. The test results on the pre- and post-tests values showed significant differences (see table 3). The pretest and post-test confirmed that there was an increasing of knowledge of health cadres. It is considered good value if the health cadres could answer the value of True as much as $\geq 6$. 
Vita Priantina Dewi, Raden Irawati Ismail, MF Lindawati Kusdhany | ASEAN Journal of Community Engagement | Volume 2, Number 1, 2018

Table 3. The significant differences between mean of pre-test and post-test values

\begin{tabular}{|c|c|c|c|c|}
\hline $\begin{array}{c}\text { No Characteristics } \\
(n=186)\end{array}$ & $\begin{array}{r}\text { Mean } 95 \% \mathrm{o} \\
T\end{array}$ & $\begin{array}{l}\text { f Interval } \\
\text { rust }\end{array}$ & p Value & $\begin{array}{c}\text { Grouping } \\
\text { Values }\end{array}$ \\
\hline $1 \quad$ Pre-test & 4.91; & $\begin{array}{l}5 \\
4 \\
4\end{array}$ & 0.000 & $\begin{array}{l}\text { value }<6(57 \%) \\
\text { value } \geq 6(44 \%)\end{array}$ \\
\hline $\begin{array}{ll}2 & \text { Post-test }\end{array}$ & 6.09 ; & $\begin{array}{l}6 \\
6\end{array}$ & 0.000 & $\begin{array}{l}\text { value }<6(32 \%) \\
\text { value } \geq 6(68 \%)\end{array}$ \\
\hline
\end{tabular}

Affective assessment of health cadres to patients by facilitators included: the way health cadres interview patients ranges at value of good-very good (69\%); the friendliness of health cadres in interviewing patients ranges at value of friendly-very friendly (77\%); and the patience of interviewer in interviewing patients ranges at value of patience-very patience (72\%). Friends' assessment of health cadres on how to interview ranges at value of good-very good (84\%), assessment of friendliness of health cadres in interviewing patients ranges at level of friendly-very friendly (93\%), the patience of health cadres in interviewing patient ranges at level of patient-very patient (90\%). Self-assessment of health cadres in interviewing patients ranges at level of goodvery good (74\%), the friendliness in interviewing patients reached $83 \%$, and the patience as an interviewer reached $79 \%$. All aspects showed the achievement on expected affective aspects reached $60 \%$ (see table 4 ).

Table 4. Affective assessment of participants

\begin{tabular}{|c|c|c|c|c|}
\hline \multirow{2}{*}{$\begin{array}{l}\text { No } \\
1\end{array}$} & \multirow{2}{*}{$\begin{array}{l}\text { Evaluator } \\
\text { Facilitator }\end{array}$} & \multirow{2}{*}{$\begin{array}{l}\text { Assessment } \\
\text { The way of interviewer interviews }\end{array}$} & \multicolumn{2}{|c|}{$n=186 \%$} \\
\hline & & & & \\
\hline & & Less well - Good enough & 58 & 31 \\
\hline & & Good - Very Good & 128 & 69 \\
\hline & & The friendliness of interviewer & & \\
\hline & & Less friendly - Friendly enough & 42 & 23 \\
\hline & & Friendly - Very friendly & 144 & 77 \\
\hline & & The patience of interviewer & & \\
\hline & & Less patient - Patient enough & 52 & 28 \\
\hline & & Patient - Very patient & 134 & 72 \\
\hline \multirow[t]{6}{*}{2} & Friend & $\begin{array}{l}\text { The way of interviewer interviews } \\
\text { patients }\end{array}$ & 29 & 16 \\
\hline & & Less well - Good enough & 157 & 84 \\
\hline & & $\begin{array}{l}\text { The friendiness of interviewer } \\
\text { Less friendly - Friendly enough }\end{array}$ & 13 & 7 \\
\hline & & Friendly - Very friendly & 173 & 93 \\
\hline & & The patience of interviewer & & \\
\hline & & Less patient - Patient enough & 18 & 10 \\
\hline
\end{tabular}


Vita Priantina Dewi, Raden Irawati Ismail, MF Lindawati Kusdhany | ASEAN Journal of Community Engagement | Volume 2, Number 1, 2018

\begin{tabular}{|c|c|c|c|c|}
\hline \multirow[t]{2}{*}{ No } & \multirow[t]{2}{*}{ Evaluator } & \multirow{2}{*}{$\begin{array}{l}\text { Assessment } \\
\text { Patient - Very patient }\end{array}$} & \multicolumn{2}{|c|}{$n=186 \%$} \\
\hline & & & 168 & 90 \\
\hline \multirow[t]{9}{*}{3} & Self & The way of interviewer interviews & & \\
\hline & & Less well - Good enough & 49 & 26 \\
\hline & & Good - Very Good & 137 & 74 \\
\hline & & The friendliness of interviewer & & \\
\hline & & Less friendly - Friendly enough & 32 & 17 \\
\hline & & Friendly - Very friendly & 154 & 83 \\
\hline & & The patience of interviewer & & \\
\hline & & Less patient - Patient enough & 39 & 21 \\
\hline & & Patient - Very patient & 147 & 79 \\
\hline
\end{tabular}

The evaluation of role of health cadres in group discussions are as follows. 88\% of health cadres actively shared their opinions. 95\% of health cadres actively provided response. $98 \%$ of health cadres were actively involved in fair discussions while $95 \%$ of health cadres were not dominating the discussions. The results of the health cadre's participation were as expected.

The results of behavioural analysis in group discussions are as follows. 93\% of health cadres presented on time. 88\% of health cadres had an active communication behaviour. The interaction in the training was good and the participants had disciplined behaviour (see table 5).

Table 5. Evaluation of the role and behaviour of health cadres
Characteristics
$\mathrm{n}=\mathbf{1 8 6}$
$\%$

\begin{tabular}{cll}
\hline ROLE & & \\
\hline Sharing opinions & & 12 \\
\hline Less & 23 & 88 \\
\hline Sometimes - Always & 163 & \\
\hline Provided responses & & 4,6 \\
\hline Less & 5 & 95,4 \\
\hline Sometimes - Always & 103 & \\
\hline $\begin{array}{l}\text { Actively involved } \\
\text { discussions }\end{array}$ & 4 & 2 \\
\hline Less & 182 & 98 \\
\hline Sometimes - Always & & 5 \\
\hline Dominant & 9 & 95
\end{tabular}


Vita Priantina Dewi, Raden Irawati Ismail, MF Lindawati Kusdhany | ASEAN Journal of Community Engagement | Volume 2, Number 1, 2018

Characteristics $\quad \mathrm{n}=186 \quad \%$

\begin{tabular}{cll}
\hline BEHAVIOR & & \\
\hline Presence & & \\
\hline Late & 13 & 7 \\
\hline On time & 173 & 93
\end{tabular}

\section{Communication}

\begin{tabular}{lll}
\hline Less & 22 & 12 \\
\hline Sometimes - Always & 164 & 88 \\
\hline
\end{tabular}

\subsection{Results of assessment of training feedback}

Feedback of participants' evaluation on training module shows that $82 \%$ of participants stated that the module was good-very good. For assessment of implementation on module learning, $83 \%$ of participants stated that the implementation on module learning was suitable-very suitable with the module contents. Health cadres assessed that the learning objectives of the module was achieved. This is evident as $90 \%$ of them stated that the learning process itself was adequately achieved- fully achieved. $77 \%$ of health cadres stated that teachers' performance in carrying out the learning process was good-very good. The learning process evaluation system achieved good-very good value $(80 \%)$. Overall, the feedback indicated that the training was successful (see table 6).

Table 6. Training feedback

\begin{tabular}{|c|c|c|c|}
\hline No & Characteristics & $n=186$ & $\%$ \\
\hline \multirow[t]{3}{*}{1} & $\begin{array}{l}\text { Participants evaluation on training } \\
\text { module }\end{array}$ & & \\
\hline & Less good - Good enough & 34 & 18 \\
\hline & Good - Very good & 152 & 82 \\
\hline \multirow[t]{3}{*}{2} & $\begin{array}{l}\text { Implementation on module learning, } \\
\text { suitability with the module contents }\end{array}$ & & \\
\hline & Less suitable - Suitable enough & 32 & 17 \\
\hline & Suitable - Very suitable & 154 & 83 \\
\hline \multirow[t]{3}{*}{3} & $\begin{array}{l}\text { Learning objectives of the } \\
\text { module was achieved in the }\end{array}$ & & \\
\hline & Not achieved - Less achieved & 19 & 10 \\
\hline & $\begin{array}{l}\text { Adequately achieved - Fully } \\
\text { achieved }\end{array}$ & 167 & 90 \\
\hline \multirow[t]{3}{*}{4} & $\begin{array}{l}\text { Teachers in carrying out the } \\
\text { learning process }\end{array}$ & & \\
\hline & Less good - Good enough & 43 & 23 \\
\hline & Good - Very good & 143 & 77 \\
\hline
\end{tabular}


Vita Priantina Dewi, Raden Irawati Ismail, MF Lindawati Kusdhany | ASEAN Journal of Community Engagement | Volume 2, Number 1, 2018

\begin{tabular}{llll}
\hline No & Characteristics & $\mathrm{n}=186$ & $\%$ \\
\hline 5 & Learning process evaluation system & & \\
\hline & Less good - Good enough & 37 & 20 \\
\cline { 2 - 4 } & Good - Very good & 149 & 80 \\
\hline
\end{tabular}

\subsection{Training of Health Workers}

The training of health workers was conducted in two stages. The first stage was a refresher training for health workers who have attended previous training (first group). A total of 12 health workers attended this refresher training in order to become the second group trainers by using DETECTION MODULES OF COGNITIVE STATUS USING HOPKINS VERBAL LEARNING TEST (INDONESIAN VERSION). Furthermore, as many as 3 trained health workers performed training under the supervision of facilitator teams. The number of trainees was 21 health workers consisting of 3 doctors, 3 midwives and 15 nurses. A pre-test was conducted before the training while a post-test was conducted after the training (see table 7).

The result of the pre-test showed that health workers who could answer correctly six or more than six questions were 8 people. In the post-test, health workers who could answer correctly six or more than six questions were 20 people. This result showed improvement of knowledge. The Delta value, which was the difference between posttest and pre-test results, indicated that this training was useful. There was one participant who did not reach the passing grade limit. This participant was directly guided by facilitators in order to understand the various obstacles and was also directed to overcome the difficulty. Overall, the training of health workers showed an increase in cognitive value.

Table 7. Grouping values and significant differences between mean of pre-test and posttest values

\begin{tabular}{llllll}
\hline No & $\begin{array}{l}\text { Characteristics } \\
(\mathbf{n = 2 1 )}\end{array}$ & Mean & $\begin{array}{c}\text { 95\% of } \\
\text { Interval } \\
\text { Trust }\end{array}$ & p Value & Grouping Values \\
\hline 1 & Pre-test & 5.1 & $4.58 ; 5.71$ & 0.000 & $\begin{array}{l}\text { value }<6(13 \\
\text { participants) value } \geq 6 \\
\text { (8 participants) }\end{array}$ \\
\hline 2 & Post-test & 8.5 & $7.63 ; 9.42$ & 0.000 & $\begin{array}{l}\text { value }<6(1) \\
\text { participant }) \text { value } \geq 6 \\
(20 \text { participants })\end{array}$ \\
& & & & \\
& & & & \\
\hline
\end{tabular}

The affective assessment was derived from an appraisal by friends on the interviewer, friendliness and patience aspects. More than half of the participants judged the manner of the interview as good-very good. Also, more than half of the participants judged the patience and friendliness as good-very good. The self-assessment result showed that almost all participants judged interviewers' performance, friendliness and patience during the interview as well-very well. Similarly, assessment of the facilitators 
Vita Priantina Dewi, Raden Irawati Ismail, MF Lindawati Kusdhany | ASEAN Journal of Community Engagement | Volume 2, Number 1, 2018

showed that most of participants judged the ways of the interview was good-very kind, friendly and patience. All aspects showed the expected affective achievement (table 8).

Table 8. The affective assessment of training participants

\begin{tabular}{ll}
\hline Appraisal by: & n (21) \\
\hline FRIEND & \\
\hline Affective on interviewer & 3 \\
\hline Less good - Good enough & 18 \\
\hline Good - Very good & \\
\hline Friendliness of interviewer & 1 \\
\hline Less friendly - Friendly enough & 20 \\
\hline Friendly - Very friendly \\
\hline The patience of interviewer \\
\hline Impatient - Rather patient \\
Patient - Very patient \\
\hline SELF
\end{tabular}

Affective on interviewer

\begin{tabular}{ll}
\hline Less good - Good enough & 2 \\
\hline Good - Very good & 19
\end{tabular}

Friendliness of interviewer

\begin{tabular}{ll}
\hline Less friendly - Friendly enough & 2 \\
\hline Friendly - Very friendly & 19 \\
The patience of interviewer & \\
\hline Impatient - Rather patient & 2 \\
\hline Patient - Very patient & 19 \\
\hline Facilitator & \\
\hline Affective on interviewer & 4 \\
\hline Less good - Good enough & 17 \\
\hline Good - Very good & 3 \\
\hline Friendliness of interviewer & 18 \\
\hline Less friendly - Friendly enough & \\
\hline Friendly - Very friendly & 4 \\
\hline The patience of interviewer & 17 \\
\hline Impatient - Rather patient &
\end{tabular}


The assessment in group discussion activities was on aspects of participants involvement. These included active participations in sharing opinions, responding and discussions. Overall, all participants ( 21 people) were able to get opportunities to speak up and no one tried to dominate the discussion. Participants' achievement of being involved in the training was as expected. Although 5 people came late to the training, all participants were actively involved in the sessions. Assessed interaction in the training was good and the discipline was good as well.

Table 9. Group discussion evaluation

Characteristics $(n=21)$

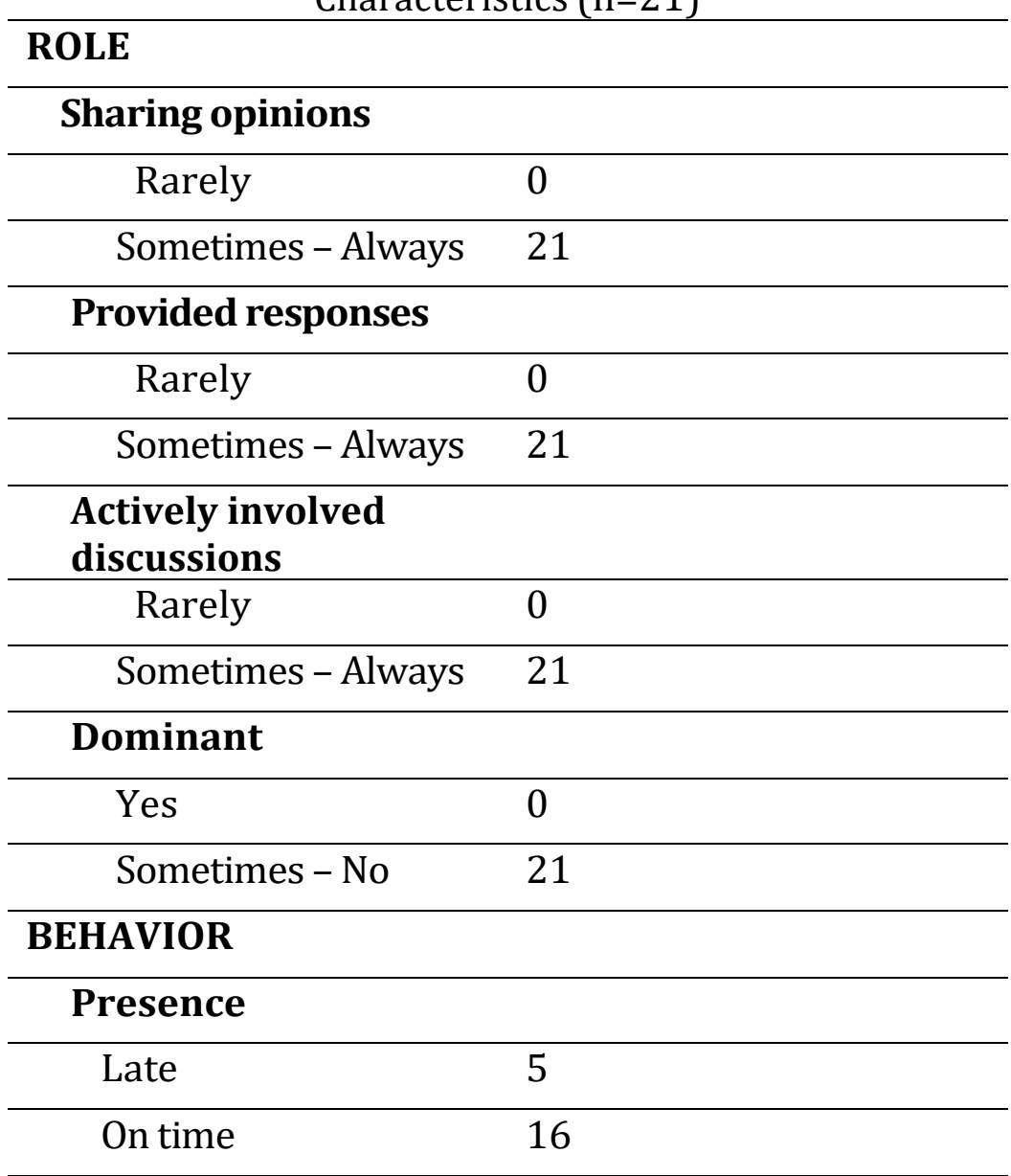

\section{Communication}

\begin{tabular}{ll}
\hline Rarely & 0 \\
\hline Sometimes - Always & 21 \\
\hline
\end{tabular}

\subsection{Results of assessment on training feedback}

All aspects of the feedback showed that the training assessment was good-very good. The assessment was rated by 17 people. The implementation was assessed by 17 people and showed reasonably value of appropriate-very appropriate. The learning objective was assessed by 19 people and showed reasonable value of quite accomplishedaccomplished. The facilitators received good-very good value from 17 participants and 
Vita Priantina Dewi, Raden Irawati Ismail, MF Lindawati Kusdhany | ASEAN Journal of Community Engagement | Volume 2, Number 1, 2018

the evaluation system received good-very good value from 18 participants. It was concluded that the training was successful.

The study suggested that education or training is often needed for health cadres and health workers who want to improve their knowledge. Also, as stated earlier, programs emphasizing on community participation was encouraged to enable people to contribute to their family, society and country. For this reason, we conducted this training for health cadres and health workers which may explain the importance of learning, education or training in life. In this case, the principles of learning on this training was to provide affordable learning opportunities for health cadres and health workers to transform their knowledge. There was no distinction between those who learn and those who teach which means those who teach shall learn and those who learn shall also teach.

In this study, there were 108 subjects in phase 1 who were included in the analysis and 186 subjects in phase 2 . Therefore, total 294 subjects were analysed. This study was a non-clinical trial, which was conducted to provide evidences on the training for health cadres, health workers and physicians to improve older persons' health and the preparedness of elderly people, cadres, health workers, and physicians to support elderly health care system in Depok City. Although the study was conducted at a designated place at the training locations which was at Universitas Indonesia, the results of our study can be used as a reference to other study in Indonesia.

Limitation of this study includes our inability to have all expected respondents to get involved in the training session since some of them had to work or could not afford transportation cost. In order to get the subjects to be able to participate, we provided transportation incentives for respondents, built good relationship with respondents, also explained the aim and benefit of the study that could be obtained by the respondents after participating in the study. The efforts to minimalize study limitation were quite successful since none of the subjects dropped out in the training.

This study demonstrated that before and after training there was an increase in participants' knowledge and skills. As mentioned earlier, the results of the training program showed that in three months, $61 \%$ of 108 health cadres showed cognitive improvement and 39\% of them needed remedial. Training feedback assessment showed that $81 \%$ up to $90 \%$ health cadres performance was good to excellent. $94 \%$ of 36 health workers showed cognitive improvement. Behavioural assessment showed $100 \%$ of respondents cooperated and could share their opinions. This study showed significant correlation between training and cognitive improvement, and also might be potential for the readiness of elderly people, cadres, health workers, and physicians to support elderly health care system, as mentioned earlier.

In addition, HVLT and MMSE trainings for medical doctor and health cadres can help in measuring cognitive status as part of community service programs. The benefits of these training especially for early detection of cognitive function impairment of the elderly is for measuring cognitive status of elderly, educating the public about prevention of decreasing in cognitive function and socialising the wider community, medical doctors and health cadres so that they can conduct examination in order to find cases of elderly people cognitive impairment. These trainings are useful for treatments to the elderly, so that they can have better quality of life, especially on the aspects of cognition. The impact of these trainings can also improve the quality of puskesmas services and posbindu lansia in early detection of the elderly cognitive status. 
Vita Priantina Dewi, Raden Irawati Ismail, MF Lindawati Kusdhany | ASEAN Journal of Community Engagement | Volume 2, Number 1, 2018

\section{Conclusions}

To conclude, the number of health cadres who were trained on the first phase was 108 people and on the second phase was 186 people, making 294 health cadres who were received the training in total. The number of health workers included doctors and nurses who have been trained on the first phase was 43 people and on the second phase was 21 people, so as a whole there were 64 health workers who received the training. This is an effort to support health care services for the elderly in Depok. Furthermore, modified instruments of MMSE and HVLT that were used to measure cognitive status of elderly people in the trainings were proven as reliable and valid instruments. Cognitive status assessment models by using modified MMSE and HVLT instruments were effectively implemented in the community.

Health workers and health cadres were very supportive and committed to support the program for elderly people. Assessment feedback of the training showed that 83\% up to $94 \%$ of participants agreed that the training was very good. The assessment also showed that 5 physicians had cognitive improvement, 2 physicians remained to have high cognitive value. 5 physicians got high ratings of affective assessment based on friendliness and patience value, 2 physicians got moderate scored, 7 of them showed their willingness to cooperate and to share their opinions. Feedback on the training of physicians showed that 7 physicians gave good-very good marks. At the end of the program, many of the health cadres and health workers at all sub-districts in Depok were already trained to conduct counselling and to do a simple measurement of cognitive status of the elderly. The success of the activities is marked by the frequency of cadres and trained health workers to be invited to the puskesmas in other areas and other posbindu to train health cadres and health workers.

To sum up, training program might be potential for cognitive improvement, and also might be potential for the readiness of elderly people, cadres, health workers, and physicians to support elderly health care system in Depok City. These trainings can be used for early detection of older people cognitive impairment to measure cognitive status of elderly, socialise prevention of decrease in cognitive function, and educate the wider community, medical doctors and health cadres so they can conduct examination to find cases of elderly people cognitive impairment.

\section{Acknowledgements}

We would like to extend our gratitude to Centre for Ageing Studies Universitas Indonesia and Directorate Research and Community Engagement Universitas Indonesia. We appreciate their kind supports and collaboration as well as hosting our meeting while we undertook the community engagement program. In particular, we extend a special thank you to Prof. Tri Budi W. Rahardjo (Director of Centre for Ageing Studies UI) and Mohammed Ali Berawi, M.Eng.Sc., Ph.D (Former Director of Directorate Research and Community Engagement Universitas Indonesia) and Ms. Yuliyanti (Research Assistant) for her tireless efforts in helping us with the FGD.

\section{References}

Arifin, E. N and Ananta, A. (2009). Facing the Geriatric Wave in Indonesia: Financial conditions and social support. In Older Persons in Southeast Asia, Arifin, Evi Nurvidya \& Ananta, Aris (Eds). Institute of Southeast Asian Studies, Singapore.

Bhardwaj, P and Duggal, S. (2009). Osteoporosis - An Orthodontic Challenge. http:www.medicastore.com/2009/1 0/osteoporosis.jpg, 
Vita Priantina Dewi, Raden Irawati Ismail, MF Lindawati Kusdhany | ASEAN Journal of Community Engagement | Volume 2, Number 1, 2018

Boedhi-Darmojo, R. (2007). Gerontologi dan Geriatri di Indonesia. Dalam: Buku Ajar Ilmu Penyakit Dalam $4^{\text {th }}$ ed., Sudoyo AW SB, Alwi I, K Simadibrata M, Setiati S. (eds.). Pusat Penerbitan IPD FKUI Jakarta, 2007: 1440-6.

De Jager, C.A., Anne-Claire, M.C., Schrijnemaekers, Thurza, E.M.H and Marc, M.B. (2009). Detection of MCI in the Clinic: Evaluation of the Sensitivity and Specificity of a Computerised Test Battery, the Hopkins Verbal Learning Test and the MMSE. Age and Ageing, 38(4):455-460.

Fidiansyah. (2010). Efektivitas Model Penilaian Status Kognitif warga Usia Lanjut dan Kualitas Hidupnya Di Pelayanan Primer Wilayah Pedesaan. Disertasi, FK UI.

Fatmah, Dewi, V.P., Yudarini and Diponegoro, S.L. (2014). Mempersiapkan Depok Sebagai Kota Ramah Lansia. Laporan Penelitian. CAS UI. Depok.

Govinda, A. (2008). Jumlah Penduduk Usia Lanjut Meningkat. Paper, page 1-2.

Hogervorst, E., Combrinck, M., Lapuerta, P., Rue, J., Swales, K and Budge, M. (2002). The Hopkins Verbal Learning Test and screening for dementia. Dement Geriatr Cogn Disord, 13(1):13-20.

Hogervorst, E and Rahardjo, T.B.W. (2007). A Pilot Study on Phytoestrogens and Dementia in Indonesia. Presented at the International Conference on Hormones, Cognitive Function and Dementia, Louborough, UK.

Irwanasir, R. (2009). Kondisi dan permasalahan Penduduk Lansia dalam Komisi Nasional Lanjut Usia. http://www.komnaslansia.or.id [01/02/2010].

Ine. (2012). Perempuan Lanjut Usia Lebih Banyak. Kompas Newspaper, page 8.

Ismail, R.I., Kusdhany, L., Iratanti and Dewi, V.P. (2014). Peningkatan Kemampuan Petugas Kesehatan Dan Kader Kesehatan Dalam Menggunakan Alat Ukur Prediksi Penyakit Osteoporosis DanPenurunan Fungsi Kognitif Pada Lansia Perempuan Melalui Pelatihan oleh Petugas Kesehatan Dan Kader Kesehatan Terlatih. Laporan Penelitian. CAS UI. Depok.

Komisi Nasional Lanjut Usia. (2011). Pengenalan Gerontologi dan Geriatri bagi Masyarakat. Jakarta.

Lubis. D. U. (2012). Psychological Aspek of Older Person in Depok. Presented at ACAP Conference Kitakyushu, Japan.

Mendes, P. P. (2009). Teaching Community Development to Social Work Students: A Critical Reflection. Community Development Journal, 44(2): 248-262.

Mukherjee, A. (2009). Frontiers in participatory rural appraisal and participatory learning and action: PRA and PLA in applied research. New Delhi: Academic Foundation.

Narayanasamy, N (2009). Participatory Rural Appraisal: Principles, Methods and Application. Los Angeles: Sage Publications.

Susanti, V. (2010). Analisis Determinan Disabilitas Lanjut Usia Indonesia. Tesis Program Pascasarjana Universitas Indonesia. Jakarta.

Tan, A. (2009). Community Development Theory and Practice: Bridging the Divide Between 'Micro' and 'Macro' Levels of Social Work. Presented at NACSW Convention, Indianapolis, IN.

Widyastuti, R.H. (2009). Pengalaman Keluarga Merawat Lanjut Usia dengan Demensia di Kelurahan Pancoran Mas, Kota Depok, Jawa Barat: Studi Fenomenologi. Tesis. FIK UI. Depok. 